\title{
THE DISTRIBUTION AND TYPE LOCALITY OF EUCALYPTUS CORDATA LABILL. - AN HISTORICAL ACCOUNT
}

\author{
by B. M. Potts
}

(with one table and one text-figure)

POTTS, B.M., 1988 (31:x): The distribution and type locality of Eucalyptus cordata Labill, --- an historical account. Pap. Proc. R. Soc. Tasm., 122(2): 31-38. ISSN 0080-4703. Department of Botany, University of Tasmania, G.P.O. Box 252C, Hobart, Tasmania, Australia 7001.

The natural distribution of the rare Tasmanian endemic Eucalyptus cordata is detailed. Discrepancics with distributional data in the literature are clarified. The type location previously indicated for the species is incorrect and the population initially collected by Labillardière at Adventure Bay in 1793 has been relocated after having eluded the attention of botanists for nearly two centuries.

Key Words: Eucalyptus, Tasmania, Labillardière.

\section{INTRODUCTION}

Eucalyptus cordata (heart-leaved silver gum) is a regional endemic confined to southeastern Tasmania. It is placed in the informal Subseries Cordatinae (Subgenus Symphyomyrtus ; section Viminales) by Pryor \& Johnson (1971). It is broadly grouped with other endemics such as $\mathbf{E}$. gunnii, $E$. morrisbyi and $E$. urnigera as well as with mainland species such as $E$. pulverulenta and $E$. cinerea (Pryor \& Johnson 1971). Affinities to E. urnigera (Mueller 1880, Brett 1938) and E. pulverulento (Mueller 1880, Baker 1902, Maiden 1913, Hall \& Brooker 1972) have been specifically noted. $E$. cordata is planted widely as an ornamental. It is usually homoblastic and the persistent, highly glaucous, cordate juvenile foliage is a distinctive feature of the species (Hall \& Brooker 1972).

Eucalyptus cordata is considered a rare and endangered species (Pryor 1981), and during a population study of the species an attempt was made to verify and sample all locations indicated on herbaria sheets (Tasmanian and Melbourne Herbaria; EUCALIST [Nov. 1983] - Chippendale \& Wolf 1984), in the taxonomic literature (Rodway 1918, Blakely 1934, Brett 1938, Hall \& Brooker 1972) and from current workers. Following this survey, it became apparent that some reports of its distribution required clarification and that the type locality previously indicated for the species (Hooker 1856, Bentham 1867, Baker 1902, Maiden 1913, Hall \& Brooker 1972) was incorrect.

\section{DISTRIBUTION}

The geographical range of E. cordata has been previously indicated by Jackson (1965), Hall \& Brooker (1972), Kirkpatrick \& Backhouse (1980) and Brown et al. (1983). The distribution of all populations verified during the present survey is indicated in figure 1 and population details given in table 1. Twenty-nine separate populations of E. cordata have been located, ranging in size from single individuals to a stand of over 5000 individuals (table 1). Its distribution is patchy and disjunct, and the supressed and scattered nature of many of the small, isolated populations is suggestive of a relict distribution pattern. In fact $E$. cordata is probably the remnant of a very early component of the Tasmanian eucalypt flora and its distribution closely follows the limits of Davies" (1974) southeastern glacial refuge. Populations are concentrated in two main geographic areas, viz. the Mt Wellington Range in the west and the general vicinity of Prosser's Sugarloaf in the east, separated by a major lowland disjunction between the Derwent and Coal Rivers. In terms of population size, the main stronghold of the species is clearly the subalpine area around Snug Plain (SP; table 1), although populations in other areas, particularly the Derwent Valley (e.g. Ml and Mo), may have been more extensive prior to agricultural development. Populations occur on Bruny and Maria Islands, both of which would have been continuous with the Tasmanian mainland during glacial periods. However, no populations of E. cordata were located south or west of the Huon Valley. 

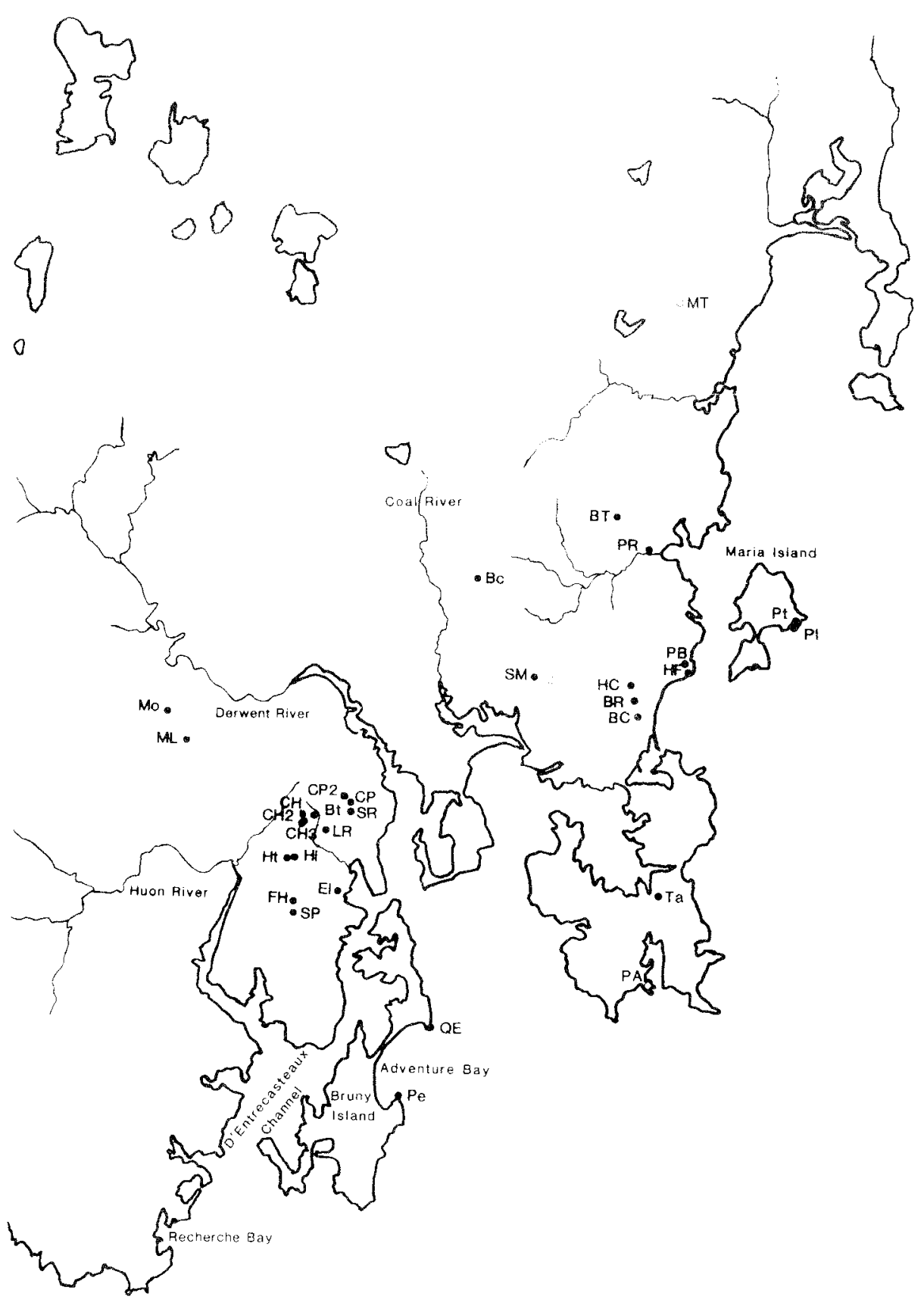

FIG. 1 - The distribution of verified ( ) and unverified $(O)$ sites of Eucalyptus cordata. Population codes are detailed in table I $(P A=$ Port Arthur $)$. 
TABLE 1

Location of Populations of $E$. cordata

\begin{tabular}{|c|c|c|c|c|c|c|c|}
\hline \multirow[t]{2}{*}{ Location } & \multirow[t]{2}{*}{ Code } & \multicolumn{2}{|c|}{$\begin{array}{l}\text { Universal } \\
\text { grid reference }\end{array}$} & \multirow{2}{*}{$\begin{array}{c}\text { Estimated } \\
\text { population } \\
\text { size }\end{array}$} & \multicolumn{2}{|c|}{ Adult foliage } & \multirow{2}{*}{$\begin{array}{l}\text { Mean } \\
\text { height } \\
(\mathrm{m})^{x}\end{array}$} \\
\hline & & $\mathbf{E} / \mathbf{W}$ & $\mathrm{N} / \mathrm{S}$ & & $\begin{array}{l}\% \text { of } \\
\text { indiv.* }\end{array}$ & $\begin{array}{c}\text { Mean } \\
\% * *\end{array}$ & \\
\hline Perpendicular Mt (top) & $\mathrm{Pt}$ & 5933 & 52766 & $300+$ & 0 & 0 & 2.8 \\
\hline Perpendicular Mt (low) & $\mathrm{Pl}$ & 5930 & 52765 & 200 & 0 & 0 & 2.9 \\
\hline Prosser River & $\mathrm{PR}$ & 5691 & 52881 & 6 & 0 & 0 & 1.3 \\
\hline Hellfire Bluff & $\mathrm{HF}$ & 5766 & 52683 & 150 & 0 & 0 & 2.0 \\
\hline Bluestone Tier & $\mathrm{BT}$ & 5652 & 52932 & 55 & 0 & 0 & 1.8 \\
\hline Bream Creek & $\mathrm{BC}$ & 5687 & 52614 & 60 & 0 & 0 & 1.9 \\
\hline Hospital Creek & $\mathrm{HC}$ & 5673 & 52660 & 150 & 0 & 0 & 2.9 \\
\hline Cape Queen Elizabeth & QE & 5345 & 52109 & 1000 & 0 & 0 & 1.7 \\
\hline Square Mountain & SM & 5506 & 52695 & 200 & 0 & 0 & 2.7 \\
\hline Electrona & $\mathrm{El}$ & 5200 & 52335 & 110 & 0 & 0 & 5.9 \\
\hline Snug Plain & SP & 5120 & 52317 & $5000+$ & 0 & 0 & 3.2 \\
\hline Falls Hill & $\mathrm{FH}$ & 5128 & 52320 & 30 & 0 & 0 & 3.7 \\
\hline Herringback (top) & $\mathrm{Ht}$ & 5113 & 52383 & 300 & 0 & 0 & 5.1 \\
\hline Herringback (low) & $\mathrm{Hl}$ & 5119 & 52385 & 300 & 0 & 0 & 4.2 \\
\hline Chimney Pot Hill & $\mathrm{CP}$ & 5225 & 52476 & 500 & 0 & 0 & 2.8 \\
\hline Leslie Road & LR & 5177 & 52431 & 200 & 0 & 0 & 4.8 \\
\hline Combes Hill & $\mathrm{CH}$ & 5140 & 52442 & 800 & 0 & 0 & 5.3 \\
\hline Mt Lloyd & ML & 4958 & 52572 & 150 & 30 & 1.5 & 7.9 \\
\hline Moogara & Mo & 4930 & 52613 & 100 & 10 & 0.2 & 15.8 \\
\hline Tarrana & $\mathrm{Ta}$ & 5714 & 52319 & 85 & 0 & 0 & 3.1 \\
\hline Brown Mountain & $\mathrm{Bc}$ & 5428 & 52837 & 150 & 50 & 3.8 & 3.3 \\
\hline Burdons Razorback & $\mathrm{BR}$ & 5671 & 52640 & 1 & 0 & 0 & - \\
\hline Combes Hill & $\mathrm{CH} 2$ & 5134 & 52432 & 300 & 0 & 0 & - \\
\hline Combes Hill & $\mathrm{CH} 3$ & 5136 & 52438 & 300 & 0 & 0 & - \\
\hline Summerleas Road & $\mathrm{SR}$ & 5220 & 52461 & 10 & 0 & 0 & - \\
\hline Chimney Pot Hill 2 & $\mathrm{CP} 2$ & 5221 & 52479 & 60 & 0 & 0 & - \\
\hline Betts Road & $\mathrm{Be}$ & 5166 & 52440 & 2 & 0 & 0 & - \\
\hline Penguin Island & $\mathrm{Pe}$ & 5301 & 52001 & 200 & 40 & 1.2 & 4.5 \\
\hline Pony Bottom Creek & $\mathrm{PB}$ & 5737 & 52712 & 40 & - & - & - \\
\hline Meredith Tier ${ }^{x x}$ & MT & 5763 & 53301 & 30 & 100 & 93.3 & 1.9 \\
\hline
\end{tabular}

* Percentage of individuals in the population developing adult or intermediate type foliage.

** Average percentage of reproductively mature foliage expressing the adult or intermediate leaf type.

$x \quad$ Average height of the individuals ( $n=10$ in the majority of cases).

$\times \quad$ Not E. cordata, see Appendix. 


\section{TYPE LOCALITY}

According to Jackson (1965). Eucalyptus cordata occurs south of the Huon Valley, in the Recherche Bay, area and the type locality of $E$. cordata has been cited as Recherche Bay by numerous authors (Hooker 1856, Bentham 1867. Baker 1902, Maiden 1913, Hall \& Brooker 1972). However, failure to locate any populations of E. cordata in this area, despite extensive searching, prompted a re-assessment of the evidence for the type locality.

Eucalyptus cordata was initially collected by Jacques Julien de Labillardière (1800), the botanist and chief scientist on the French expedition under the command of Bruni D'Entrecasteaux sent in search of the ill-fated La Pérouse expedition by the French Constituent Assembly in 1791. The expedition in the ships la Recherche and l'Espérance was in Australian waters from 1792 to 1793 and visited Tasmania twice during this period (see Maiden 1910, Hogg 1938, Stafleu 1966, Carr \& Carr 1976). E. cordata was described and illustrated in Labillardière's work on the botany of the voyage, Novae Hollandiae Plantarum Specimen in 1806. The locality for E. cordata was given as "capite van-Dieman"; the general locality given for all of his Tasmanian collections (Kantvilas 1983). E. cordata was later collected by Joseph Hooker and Ronald Gunn from the "Huon district" (Hooker 1856) and, in part 3 of his Botany of the Antartic Voyage, Hooker (1856) indicated Labillardière's locality for E. cordata to be Recherche Bay. In his Eucalyptographia, von Mueller (1880) listed several collectors who located $E$. cordata in the same region as Labillardière (Brown, Hooker, Gunn, Stephens and Abbott), yet Maiden (1913) could find no evidence for this statement.

1n a letter to Sir William Hooker, the father of Joseph Hooker, Gunn wrote of an excursion to Recherche Bay in 1838 which enabled him to identify nearly all of Labillardière's Tasmanian species (Dec. 1843, letter 184, Burns \& Skemp 1961). In the same paragraph he mentions E. cordata, although no clear indication is given as to whether or not he located this species in the area. There is a specimen of $E$. cordata attributed to Gunn at Kew with the locality given as Recherche Bay, although the specific code given (No. 1207) does not correspond to Gunn's code for E. cordata (No. 1071). This specimen has been inspected and is clearly $E$. cordata with the morphology similar to that found in the western populations of E. cordata. However, the specimen is not annotated in Gunn's handwriting, is undated and does not have one of Gunn's coded collecting labels which is atypical for Gunn's specimens. This specimen is on the same herbarium sheet as a specimen collected by Gunn from near the Huon River $(30 / 10 / 1839)$ and may have originated from this collecting trip. Furthermore, in discussing Labillardière's collections in later correspondence (letter 185, Burns \& Skemp 1961) Gunn noted "Eucalyptus cordata [Lab.] [.152. Is my own No 1071 - a species I never saw except in the Country South of Hobart Town." Where Cunn located species at Recherche Bay, this was clearly indicated in the letter and the latter comment probably refers to the area immediately south of Hobart

The specimens sent to Baron von Mueller by Abbott (MEL104507 and MEL104504) were from Huon Road (North West Bay). However, there is one specimen sent to him by T. Stephens from Recherche Bay (MEL104502 - left specimen). At the time, with von Mueller preparing his Eucalyptographia, there was considerable interest in this "rare species" and the belief that Recherche Bay was the type locality was widely held (Stephens 1882, 1889) -

".... this interesting tree, discovered and described long ago, had been lost to sight for more than forty years. It was originally reported as a denizen of Recherche Bay by the French expedition under Labillardière ; and long afterwards, in Sir John Franklin's time, it was found by Sir Joseph Hooker and the late Mr. Ronald Gunn 'in the Huon district', no precise locality having been recorded. From that time to the present it appears to have eluded the search of botanists ; and it was only in October last that, in answer to repeated enquires, specimens were at last obtained from Recherche Bay, but without flower or fruit." (Stephens 1882).

The letter accompanying the specimen read -

"Eucalyplus condata is found at last... I received from Recherche Bay a branchlet of a young Eucalypius, and this was followed by a letter from the finder stating that there was no blossom or any sign of fruit on any of the trees near" (Stephens to von Mueller, Nov. 1880).

Inspection of this specimen suggests that it is probably not $E$. cordata, but more likely a juvenile of E. globuius, which would accord with the noted absence of reproductive material. The juvenile foliage of $E$. globulus resembles the adult foliage of the western populations of E. cordata.

The belief that Recherche Bay was the type locality no doubt stemmed from Hooker's (1856) original citation, although he gave this locality for 
many of Labilardière's "capite van-Diemen" locations. Labilardière was based and collected extensively in the vicinity of Recherche Bay. He recorded collecting several species of eucalypts on the shore to the aortheast of their anchorage on 23 April 1792, but no distiguishing remarks on the species collected were given (Labillardière 1800). He later (6 Nay 1792) recorded specifically collecting $E$. globulus by felling a tree in order to obtain flowers, and designated the name for the species in his journal. However, he also collected from other aras along the D'Entrecasteaux Channel, including Bruny Island (Townrow 1978) and it is always possible he may have made multiple, unrecorded collections of single species.

Bentham (1867, vol. 3, p. 224) ascribed a specimen of Labillardière's, without flower or fruit, collected from Maria Island, to the mainland species, E. macrocarpa. In reference to this, Maiden (1913, p. 24l) later noted "Maria Island is off the coast of Tasmania, and I suggest that Labillardière's specimen is E. cordata, Labill." Labillardière did not collect on Maria Island, although collections from Maria Island were made later by Leschenault de la Tour, the botanist on the French expedition (1800-1804) commanded by Nicholas Baudin (Péron 1975). Specimens from the Baudin expedition were not described as a whole, but examined from time to time by monographers (Maiden 1910).

There is strong evidence that Labillardière accessed this collection and used some specimens in his Novae Hollandiae Plantarum Specimen, mislabelling the localities (Nelson 1974, 1975; Carr $\&$ Carr 1976). The herbarium specimen ascribed to Labillardière by Bentham has not yet been located. However, it is possible that a specimen of E. cordata was collected from the summit of Perpendicular Mountain during the Baudin expedition and has been both misidentified and mistakenly attributed to Labillardière. Nevertheless, this is not a cause of confusion and there is no doubt that Labillardière personally collected E. cordata.

Recent findings have revealed that Recherche Bay is not the type locality of E. cordata, and it follows there is no solid evidence for its occurrence in the area. In "Relation du Voyage de la Recherehe de la Pérouse", Labillardière specifically recorded collecting a eucalypt from Penguin Island while the expedition was anchored in Adventure Bay, just prior to the final departure from Tasmania. This island had been previously charted and is clearly named on charts from Captain James Cook's 1777 expedition (Triebel \& Batt 1957). Labillardière's
(1800: 76) description leaves no doubt this eucalypt is E. cordata -

"Je recueillis sur l'île aux Pinguins .... ; un eucalyptus de hauteur médiocre, qu'on reconnô̂tra facilement à ses feuilles opposées, sessiles et glauques;...."

The translation of glauque (glaucous) in the English version of his journal (1800) " ... opposite, sessile leaves, of a whitish green colour, with a slight tint of blue.." is not as botanically exact as the original, and similar, but more severe problems with the translated version have been detailed by Carr \& Carr (1976).

The occurrence of E. cordata on Penguin Island has recently been verified (14 August 1987) after having escaped the notice of botanists for nearly two centuries. The small island is dominated by Casuarina stricta low forest, with some $E$. globulus on the northern aspect, most of which has been recently burnt (March 1986). However, E. cordata occurs on the wetter, southern cliff slope which faces Fluted Cape and the majority of the population is unburnt. The population is small, comprising approximately 200 mature individuals, and cannot be missed when following the narrow ridge to the summit of the island, the path presumably taken by Labillardière in 1793. A few individuals are readily accessible from the main ridge suggesting that the type locality can be predicted to within less than $30 \mathrm{~m}$. It is even possible that the same individuals have been sampled in the present survey.

Labillardière's holotype (FI, Herb. Webbianum) and isotypes (MEL104513; G; P) of $E$. cordata are consistent with specimens collected from Penguin Island. Moreover, this population is somewhat atypical for E. cordata as approximately $40 \%$ of reproductively mature individuals had developed a very small proportion $(<5 \%)$ of adult or intermediate foliage. Such individuals are usually rare in natural populations of $E$. cordata (table 1). The opposite and glaucous juvenile type of foliage is usually fully retained throughout the life of an individual, although intermediate or adult leaves may occasionally be seen at the top of large trees (Hall \& Brooker 1972). Nevertheless, Maiden (1919) noted

"... E. cordata is one of the few remaining species with homoblastic leaves ... I would invite the further attention of collectors to this tree, in order that they may search, especially near the tops, both cultivated specimens, and trees in their native habitats, for pedicellate, lanceolate leaves. The nearest I have got to this state is in a 
specimen ( $2 \mathrm{c}$ of Plate 84 C.R.) collected by Labillardière himself."

It is possible E. cordata was also observed during Cook's 1777 visit to Adventure Bay, as a recently published sketch by William Ellis from this expedition may feature E. cordata (Joppien \& Smith 1987). Professor W. D. Jackson (on p.630) suggested plants in the foreground of the sketch, on the shore, may be wither juvenile $E$. globulus or $E$. cordata. His observations were made prior to the rediscovery of $E$. cordata on Penguin Island. The island is in the immediate vicinity of Cook's anchorage and is the only area known today where $E$. cordata grows near sea level. In fact the leaf shape, tree form and even the possible adult foliage on one of the top branches, specifically noted by Prof. Jackson, are more consistent with the $E$. cordata in this area than juvenile $E$. globulus.

Specific records of collection can be obtained for some of the 265 specimens described in Novae Hollandiae Plantarum Specimen from Labillardière's journal (Labillardière 1800). Along with the example of E. cornuta Labill., described by Carr \& Carr (1976), the present case attests to the accuracy and detail of his account. Furthermore, due to the limited size of the E. cordata population on Penguin Island, the relocation of this type locality may be one of the most exact from this early period of botanical exploration in Australia. In other cases, specific predictions of Labillardière's type localities have been made by integrating population phenological and distributional data with excursion and anchorage records (e.g. Stipa - Townrow 1978). All of the other Tasmanian eucalypts collected and described by Labillardière (1806), viz. E. ovata Labill., E. viminali. Labill., E. globulus Labill. and E. amygdalina Labill., are widespread through the areas Labillardière visited (e.g. Kirkpatrick \& Backhouse 1980). Specific mention is only made of E. globulus, although his numerous references to E. resinifera no doubt refer to E. obliqua; a species widespread in Tasmania and common in the vicinity of Recherche Bay. When describing E. ovala, Labillardière (1806) gave the locality as "terra van-Leuwin" (Western Australia), the only other area in Australia in which he collected. E. ovata is confined to southeastern Australia, including Tasmania, and this is one of the species used by Nelson $(1974,1975)$ to demonstrate that Labillardière accessed other collections as well as confused some of his own collecting localities in specimens described in Novae Hollandiae Plantarum Specimen. Nevertheless, many of the location anomalies and other problems associated with Labillardière's works have now been resolved (Nelson 1974. 1975, Carr \& Carr 1976), and Cary $\&$ Carr (1976) considered that many errors of interpretation could have been avoided with greater collaboration between botanists and historians.

\section{ACKNOWLEDGEMENTS}

I wish to thank the many people who assisted with advice on localities and field trips. Specific acknowledgements are due to W. D. Jackson, J. B. Reid, P. M. Minchin, M. J. Brown, J. B. Kirkpatrick, F. Duncan, G. Kantvilas, N. J. Davidson, D. M. J. S. Bowman, M. Gilbert, N. Hall and W. C. and R. C. Potts. I also thank G. Kantvilas for his helpful comments on an earlier draft of this manuscript. This survey was initially funded by the Tasmanian Forest Ecology Research Fund, supported by World Wildlife Fund Australia and completed while I was in receipt of an Australian Government National Research Fellowship.

\section{REFERENCES}

BAKER, R. T., 1902: On Eucalyptus cordata, Labill., and its cognate species. Aust. Assoc. Adv. of Sci. IX: 344-348.

BENTHAM, G., 1867: FLORA AUSTRALIENSIS: A DESCRIPTION OF THE PLANTS OF THE AUSTRALIAN TERRITORY. LOVell Reeve \& Co., London.

BLAKELY, W. F., 1934: A KEY TO THE EUCALYPTS. The Workers Trustees, Sydney.

BRETT, R. C., 1938: A survey of Eucalyptus species in Tasmania. Pap. Proc.R. Soc. Tasm. (1937): $75-111$

BROWN, M.J., KIRKPATRICK, J. B. \& MOSCAL, A., 1983: AN ATLAS OF TASMANIA'S ENDEMIC FLORA. The Tasmanian Conservation Trust Inc., Hobart.

BURNS, T. E. \& SKEMP, J. R., 1961: VAN DIEMEN'S LAND CORRESPONDENTS. Queen Victoria Museum. Launcesion.

CARR, S. G. M. \& CARR, D. J., 1976: The French contribution to the discovery of Australia and its flora. Endeavour 35 (124): 21-26.

CHIPPENDALE, G. M. \& WOLF, L. J., 1984: EUCALIST: Computerized Data Retrieval System for Eucalytpus (Myrtaceae). Aust. For. Res. 14: 147-152.

DAVIES, J. L. 1974: Quaternary Environments. In Williams, W.D. (Ed.): BIOGEOGRAPHY AND ECOLOGY IN TASMANIA. W. Junk, The Hague: $17-27$. 
HALL, N \& BROOKER, I., 1972: Heart-leaved Silver Gum: Eucalyptus cordata Labill. Forest Tree Series No. 53. A.G.P.S., Canberra.

HOGG, G. H., 1938: D'Entrecasteaux: An account of his life, his expedition, and his officers. Pap. Proc. R. Soc. Tasm. (1937): 53-74.

HOOKER, J. D., 1856: THE BOTANY OF THE ANTARCTIC VOYAGE. PART 3. FLORA TASMANIAE. Lovell Reeve, London.

JACKSON, W. D., 1965: Vegetation. In Davies, J. L.(Ed.): ATLAS OF TASMANIA. Lands and Mercury Press, Hobart: 30-34.

JOPPIEN. R. \& SMITH, B. 1987: THE ART OF CAPTAIN COOK'S VOYAGES: THE VOYAGE OF THE RESOLUTION AND DISCOVERY 1776-1780. Vol.3, Oxford University Press, Melbourne: plate ii.

KANTVILAS, G., 1983: A brief history of lichenology in Tasmania. Pap. Proc. R. Soc. Tasm. 117: $4 \mid-51$.

KIRKPATRICK, J. B. \& BACKHOUSE, S., 1980: ILLUSTRATED GUIDE TO TASMANIAN NATIVE TREES. Mercury-Walch, Hobart.

LABILLARDIĚRE, J. J., 1800: RELATION DU VOYAGE A LA RECHERCHE DE LA PÉROUSE. Paris.

LABILLARDIĖRE, J. J., 1804-1807: NOVAE HOLLANDIAE PLANTARUM SPECIMEN. Vol. 11. Paris.

MAIDEN, J. M., 1910: Records of the earlier French Botanists as regards Australian plants. J. R. Soc. N.S.W. 44: 123-155.

MAIDEN, J. M., 1913: A CRITICAL REVISION OF THE GENUS EUCALYPTUS. Vol. 2. Government Printer, Sydney. : pts 17-19.

MAIDEN, J.M., 1919: Notes on Tasmanian eucalypts. $J$. R. Soc. N.S.W. 53: 82-90.

NELSON, E. C., 1974: The locations of collection and collectors of specimens described by Labillardière in "Novae Hollandiae Plantarum Specimen": additional notes. Pap. Proc. R. Soc. Tasm. 108: 159-170.

NELSON, E. C., 1975: The collectors and type locations of some of Labillardière's "Terra Van-Leuwin" (Western Australia) specimens. Taxon 24: 319-336.

PÉRON, M.F., 1975: A VOYAGE OF DISCOVERY TO THE SOUTHERN HEMISPHERE. Marsh Walsh Publishing, North Melbourne.

PRYOR, L. D., 1981: AUSIRALIAN ENDANGERED SPECIES : EUCALYPTS. Spec. Publ. 5. Aust. Nat. Pks Wildl. Serv.

PRYOR, L. D. \& JOHNSON, L.A.S., 1971: A CLASSIFICATION OF THE EUCALYPTS. A.N.U. Press, Canberra.

RODWAY, L., 1918: Tasmanian eucalypts. Pap. Proc. R. Soc. Tasm. (1917): 10-20.

STAFLEU, F. A., 1966: Introduction to facsimile edition of Novae Hollandiac Plantarum Specimen (Labillardière 1804), Historiae Naturalis Classica, Weinheim.
STEPHENS, T., 1882: Note 27. Specimen of Eucalyptus cordata. Pap. Proc. R. Soc. Tasm. (1881): iv.

STEPHENS, T., 1889: Notes and Exhibits. Pap. Proc. R Soc. Tasm. (1888): xxxiii.

TOWNROW, J. E. S., 1978: Stipa L. in Tasmania historical notes: Taxonomic contributions 1768-1968 and the type locality of Stipa flavescens Labill. Pap. Proc. R. Soc. Tasm. 112: $215-226$.

TRIEBEL, L. A. \& BATT, J. C., 1957: FRENCH EXPLORATION OF AUSTRALIA WITH SPECIAL REFERENCE TO TASMANIA. Tasmanian Government Printer, Hobart.

VON MUELLER, F., 1880: EUCALYPTOGRAPHIA. ATLAS OF THE EUCALYPTS OF AUSTRALIA AND THE ADJOINING ISLAND. Trubner and Co., London.

(accepted 25 November 1987)

\section{APPENDIX}

\section{Additional notes}

Several additional anomolous records of E. cordata were found which require further comment.

\section{Meredith Tier (MT)}

The northernmost population indicated in Brown et al. (1983) on Meredith Tier (MT) was not included within $E$. cordata and its exact affinities require further investigation. When this population was originally located by F. Duncan, it was regenerating from wildfire and the original specimen collected bore capsules in the juvenile foliage stage. However, when sampled several years later, all reproductively mature individuals had developed adult foliage. The exact affinities of this population are masked by what appears to be extensive hybridisation with the nearby $E$. barberi. This population is within the climatic range of E. cordata as predicted using the climatic model BIOCLIM (Potts \& Minchin, unpubl. data). However, the closest and northernmost stand of E. cordata is on Bluestone Tier (BT) which is over $40 \mathrm{~km}$ south of this site. The population on Meredith Tier may have closer affinities to E. gunnii, the nearest population of which occurs only $7 \mathrm{~km}$ away, near Tooms Lake. 


\section{Brown Mountain, Port Arthur (PA)}

The Port Arthur and Brown Mountain locat ions noted by Bret1 (1938) and Rodway (1918) respectively correspond to herbarium specimens (HO 15629-32, 15637-39, 15660-62, 16077) they independently collected from Brown Mountain near Port Arthur. This population was not relocated despite extensive searching. Some of Rodway's specimens (initially labelled $E$. globulus var. Harrisoni e.g. HO 16077) from this location were noted as collected from tall trees $(33-66 \mathrm{~m})$, whereas the vegetation in this specific area is low mallee and no stands could be found in taller, wetter forests nearby. Brett's specimen from the same location is annotated as being an E. globulus $\mathrm{x}$ cordata hybrid and that the E. cordata in the area was an undershrub growing in association with E. globulus. Intermediate or adult foliage occurs on some of these specimens. In this respect, the resemblance between some of the specimens collected by Rodway and Brett from Brown Mountain and those from the type locality is noteworthy and may account for Brett's (1938) record of hybridisation between $E$. globulas and E. cordata.

\section{Brown Mountain, Campania (Bc)}

The Brown Mountain (Bc) sampled in the present survey occurs near Campania and is no doubt the Brown Mountain and Campania locations given by Brett (1938) and Rodway (1918) respectively. Brett's Port Arthur locality probably corresponds to his specimens from the Brown Mountain near Port Arthur. While individuals developing intermediate type foliage were found in the population on Brown Mountain near Campania (table 1), this mountain is unlikely to have been confused with the locality collected by Rodway or Brett from near Port Arthur (PA; see above). The population near Campania is low mallee, there is no E. globulus in the vicinity and the specimens do not correspond to samples collected from this population. The population $(\mathrm{Bc})$ showed some affinities to $E$. urnigera in capsule shape and juvenile leaf shape, but the majority of individuals developed flowers in the juvenile leaf stage. While this stage is not fully persistent (table 1), it has been included within $E$. cordata for the present survey. In this respect it is significant that Brett (1938) indicated $E$. cordata had affinities to E. unigera and von Mueller (1880) noted:

"Crenulate leaves occur also in E. urnigera, and, strange as it may appear, it is to this species that $E$. cordata bears the closest alliance; for although the aged state of $E$. urnigera has scattered longstalked dark-green and lanceolar-sickleshaped leaves, more slender elongated and downward more attenuated calyces on conspicuous stalklets with ampler lid and urnshaped fruits with deeply enclosed valyes, yet trees are now known (through Mr. Stephens from "Old Man's Head", a subalpine mountain near Lake Cresent) [no doubt Alma Tier], which to all appearance form a complete transit from $E$. urnigera to $E$. cordata. Moreover Mr. Aug. Oldfield sent many years ago from the middle regions of Mount Wellington sterile saplings as the young state of $E$. urnigera, the adventitious lower shoots of which can in no way be distinguished in foliage from $E$. cordata and which are also partly pruinous. On the summit of Mount Wellington I collected a state of E. urnigera, with all leaves nearly oval and with simply truncate-ovate fruits."

\section{Nelson's Tier}

The Nelson's Tier location noted by several authors (Stephens 1889, Blakely 1934, Brett 1938) probably corresponds to the population sampled on the contiguous Square Mountain (SM), although the possibility of other populations in this general locality can not be discounted.

\section{Fisherman's Island}

The present day locality of Abbott's specimen collected in 1881 (MEL104503) and labelled "Fisherman's Island" is unclear. This specimen corresponds to the morphology found in the western populations and does not correspond to samples from Maria (Pt, PI) or Bruny (QE, Pe) Islands. 